\title{
THE ENHANCEMENT OF PRE-SERVICE MATHEMATICS TEACHERS' MATHEMATICAL UNDERSTANDING ABILITY THROUGH ACE TEACHING CYCLIC
}

\author{
Muhammad Win Afgani ${ }^{1}$ (D), Didi Suryadi ${ }^{2}$, Jarnawi Afgani Dahlan ${ }^{2}$ (D) \\ ${ }^{1}$ Raden Fatah State Islamic University (Indonesia) \\ ${ }^{2}$ Indonesia University of Education (Indonesia) \\ mubammadwinafgani_uin@radenfatah.ac.id,ddsuryadi1@gmail.com,jarnawi@upi.edu
}

\author{
Received April 2018 \\ Accepted October 2018
}

\section{Abstract}

The aim of this study was to investigate the enhancement of the mathematical understanding ability of pre-service mathematics teachers through Activity-Class discussion-Exercise (ACE) teaching cyclic based on APOS theory. This study used a quasi-experiment method with non-equivalent pre-post test control group design. The subjects of this study were 120 pre-service mathematics teachers from two universities in Palembang, Indonesia. The subjects were divided into two classes, that are, experiment and control class. Experiment class was a class that is applied ACE teaching cyclic based on APOS theory, whereas control class was a class that is applied direct learning. The subjects were also divided into three groups of mathematical initial ability, that are, high, average, and low. The Instruments used in this study were mathematical initial ability test, mathematical understanding ability test, observation, and interview. Data analysis tests used in this study were statistic test of parametric and non-parametric. The results of data analysis showed that 1) there is no significant difference between the enhancement of mathematical understanding ability of pre-service mathematics teachers applied ACE teaching cyclic based on APOS theory and direct learning in terms of overall and group of mathematical initial ability, 2) there is no interaction between learning factors (ACE teaching cyclic and direct learning) and group of mathematical initial ability (high, average, and low) to the enhancement of mathematical understanding ability of preservice mathematics teachers.

Keywords - Mathematical understanding ability, ACE teaching cyclic, APOS theory.

\section{To cite this article:}

Afgani, M.W., Suryadi, D., \& Dahlan, J.A. (2019). The enhancement of pre-service mathematics teachers' mathematical understanding ability through ACE teaching cyclic. Journal of Technology and Science Education, 9(2), 153-167. https://doi.org/10.3926/jotse.441

\section{Introduction}

Mathematical thinking means doing math or mathematical task. To obtain mathematical understanding competency, students need to understand mathematics well. Nevertheless, it is an uneasy to achieve. This is because, according to Ernest (2004), mathematics is classified as a priori knowledge consists of theorems that are expressed as arguments without observation from the real world. The arguments are covering deductive logic, definition, and sets of assumption from axioms and postulates used as a base to conclude mathematics knowledge. Therefore, an individual that has mathematical understanding will be 
able to use this ability to learn mathematics without any significant difficulties and can think mathematically where the way of thinking is very useful in everyday life (Stacey, 2006).

An individual can understand mathematics when s/he has comprehended mathematics object structure. The result of Afgani, Suryadi and Dahlan (2017) study showed that most of the students' mathematical understanding ability is still in action conception based on APOS theory perspective or instrumental understanding according to Skemp (1976). The other studies that reported students' mathematical understanding ability are not optimal yet were Maharaj (2010), De Castro (2011), Syahbana (2013), Salleh dan Zakaria (2013), Rosita, Laelasari and Noto (2014), Siyepu (2015), Mrdja, Romano and Zubac (2015), and Ningsih (2016). Therefore, a pedagogic approach needs to be applied to improve that students' ability. A pedagogic approach that is needed as one of that solution is an approach that can construct students' mathematics knowledge. Jojo (2013) stated an individual get mathematics understanding through mental construct from direct experience that relevant with mathematics concept. Mathematics knowledge obtained by an individual relate directly to how s/he construct it. Psychology philosophy explains the process of an individual knowledge formation is constructivism. This philosophy believes that an individual construct and obtain the essence of knowledge through her/his interaction with others (Zahid, Sujadi \& Sari, 2014).

In genetic epistemology of Piaget, every individual has initial knowledge structure (Schemata). When s/he interacts with others, assimilation and accommodation process occur between schemata and new experience. The experience develops to a new schema. Both processes can ensue imbalance. The changing condition from disequilibrium to equilibrium can develop an individual knowledge (Zahid et al., 2014). That processes completely each other directing an individual to adapt. According to Simatwa (2010), Adaptation is congenital tendencies of an individual to interact with her/his environment. The interaction contributes the development of the complex mental structure. S/he assimilates through experiences and adjusts to her/his mind development structure when s/he sustains new experience which is s/he needs time to adapt to existing accommodation structure. This theory was developed especially by Dubinsky (Arnon, Cottrill, Dubinsky, Oktac, Fuenstes, Trigueros et al., 2014) in learning mathematics that is called APOS theory.

Arnon et al. (2014) implied that APOS theory focus on possibility model may occur in an individual mind when s/he tries to learn mathematics. According to this theory, to understand mathematics, an individual get started through manipulating previous mental construction in her/his mind to form actions. The actions will be explored to form processes and then simplified to form objects. The objects can be elaborated back to processes where they were formed. At last, all of that organized into schemas (Jojo, 2013). Mathematical understanding formed is an individual ability to construct and reconstruct mathematics knowledge through action, process, object, and organize them into schema (Syaiful, 2014). A pedagogic approach suggested by this theory is applying ACE (Activity-Class discussion-Exercise) Teaching Cyclic (Asiala, Brown, DeVries, Dubinsky, Mathews \& Thomas, 1996). In the first phase, Activity is designed to accelerate the development of students' mental structure by utilizing mathematics application program in the computer laboratory. In the second phase, students discuss in class with teacher guidance to reflect activity in computer laboratory that is connected to deep mathematical understanding. In the third phase, students' commit mathematics task outside class to reinforce their mathematics knowledge. The three phases occur cyclically to achieve the learning objective.

The construction of mathematics knowledge undertaken by students during ACE teaching cyclic based on APOS theory denotes the process of students' mathematics understanding. Whether their mathematical understanding ability will enhance after a pedagogic approach according to APOS theory is applied to them? That problem becomes a focus of this study. Based on the background has been described above, Research problems in this study, that is, as follows:

1. Is there enhancement of mathematical understanding ability between pre-service mathematics teachers applied ACE teaching cyclic based on APOS theory with pre-service mathematics teachers applied direct learning in terms of overall or mathematical initial ability group? 
2. Is there an interaction between learning factor (ACE teaching cyclic and direct learning) and the group of mathematical initial ability (high, average, and low) to the enhancement of the mathematical understanding ability of pre-service mathematics teachers?

Based on the research problems, the objectives of this study were:

1. To study comprehensively the difference enhancement of mathematical understanding ability between pre-service mathematics teachers applied ACE teaching cyclic based on APOS theory with pre-service mathematics teachers applied direct learning in terms of overall or mathematical initial ability group

2. To study comprehensively the interaction between learning factor (ACE teaching cyclic and direct learning) and mathematical initial ability group (high, average, and low) to the enhancement of the mathematical understanding ability of pre-service mathematics teachers?

The results of this study are expected to be useful for:

1. The lecturers as a contribution to be considered that ACE teaching cyclic based on APOS theory is an alternative to teach mathematics can be applied to undergraduate students'.

2. Undergraduate students' as a learning experience that can develop their mathematical understanding ability.

3. Researcher as a medium to improve investigation ability about developing ACE teaching cyclic based on APOS theory in learning mathematics.

\section{Research Method}

The method of this study used a quasi-experimental method with non-equivalent pretest and posttest control group design. Variables in this study consisted of independent, dependent, and control variable. Independent variable was ACE teaching cyclic based on APOS theory, the dependent variable was mathematical understanding ability, and control variable was a mathematical initial ability which is divided into high, average, and low. Dependent variable investigated comprehensively in terms of learning factor, mathematical initial ability group, and students overall. The subject of this study was 120 pre-service mathematics teachers from two universities in Palembang, South Sumatera, Indonesia. The subjects were divided into two class, that is, experiment and control class. Experiment class was a class that is applied ACE teaching cyclic based on APOS theory with 62 students, whereas control class was a class that is applied direct learning with 58 students. The subjects were also divided into three groups of mathematical initial ability, that is, high, average, and low.

\subsection{Instruments and Data Collection Technique}

There was one variable measured in this study, that is, mathematical understanding ability in terms of learning factor, group of mathematical initial ability, and students overall. For that, an instrument of the test was designed to fulfill validity and reliability. The instruments consisted of mathematical initial ability test as a tool to place the students in a group of ability and mathematical understanding ability test as a tool to know the level of students' mathematical understanding ability. The result of mathematical initial ability test was used to know data homogeneity of experiment and control class, and also to dispose of the students based on a group of mathematical initial ability, whereas mathematical understanding ability test was used as pre and posttest. This aimed to know the improvement of that ability. Both instruments were tested through the face and construct validity before they are used in a field test. There were 4 doctors in mathematics education as the expert to review and validate both instruments. Face validity is based on sentence clarity and the presentation, whereas construct validity is based on question suitability with a subject matter and degree of difficulty. After that, the results were tested with Q-Cochran test. Consideration and recommendation from the experts became a reference to revise. The instruments have revised was experimented to students who had attended calculus differential class. Validity and reliability 
test were assisted by SPSS program. Validity test used Corrected Item Total Correlation and reliability test used Cronbach Alpha.

In this study, a mathematical initial ability is students' mathematical ability before a pedagogic approach is applied to them. The aims of mathematical initial ability were to know data homogeneity of students' mathematical ability at experiment and control class as well as students placement based on ability group (high, average, and low). Material tested to measure mathematical initial ability was calculus preliminary with 14 items. The aim of this test was to know students' mathematical procedural ability which according Bautista (2013), the ability is influenced by mathematical ability in algebraic or trigonometry. The items of test concerned with real numbers system, quadratic equation, inequality, Cartesian coordinate system, graphic, and function. Items in the instrument test were compiled in essay form. The following is one of the items used to test students' mathematical initial ability:

Find the domain of

a) $g(x)=\frac{\sqrt{x}}{x^{2}+1}$

b) $h(x)=\sqrt{4-x}+\sqrt{x^{2}-1}$

The Result of Q-Cochran test of mathematical initial ability Test from 4 experts showed that asymp. sig value of face validity is 0.112 and construct validity is 0.392 which both values are greater than $\alpha=0.05$. It means that there was no difference consideration of face and constructs validity of 14 items in mathematical initial ability test instrument from 4 experts. From that result, the experts recommended to test it to students who had attended calculus differential class.

The experiment of mathematical initial ability test instrument to students who had attended calculus differential class aimed to know the sentence legibility level and to get a description of their problem understanding. The data result was tested again with validity and reliability test. Every item was given a score between $0-3$. The test was held to 34 students. The result of validity test showed that the Pearson Correlation coefficients of every item are greater than the critical value $\left(r_{x y}=0.3388\right)$ and reliability test showed that Cronbach Alpha test is $r_{11}=0.841$. It means that 14 items in mathematical initial ability test instrument were valid and very reliable to measure calculus initial ability of pre-service mathematics teachers.

Hereinafter, we tested validity and reliability of mathematical understanding ability test. Materials tested in the instrument consist of the limit of function and derivatives. Items in the instrument test were compiled in essay form with 8 problems. Indicators of the items covered 1) calculate with procedure correctly, 2) identify and explain a concept, 3) represent a concept in another form, 4) prove the validity of a statement, 5) apply a concept in problem-solving. The following is one of the items used to test students' mathematical understanding ability on the $5^{\text {th }}$ indicator:

Let the vertices of rectangle $R$ joining the midpoints of the sides of the quadrilateral $Q$. The vertices of $\mathscr{Q}$ were $(-x, 0),(x, 0),(0,-1)$ and $(0,1)$. Investigate, is the $\lim _{x \rightarrow 0^{+}} \frac{\text { Perimeter } R}{\text { Perimeter } Q}=\lim _{x \rightarrow 0^{-}} \frac{\text { Area } R}{\text { Area } Q}$ ?

The result of Q-Cochran test of mathematical understanding ability Test from 4 experts showed that asymp. sig value of face validity is 0.112 and construct validity is 0.392 which both values are greater than $\alpha=0.05$. It means that there was no difference consideration of face and constructs validity of 8 items in mathematical understanding ability test instrument from 4 experts. From that result, the experts recommended to test it to students who had attended calculus differential class.

The experiment of mathematical understanding ability test instrument to students who had attended calculus differential class aimed to know the sentence legibility level and to get a description of their problem understanding. The data result was tested again with validity and reliability test. Every item was given a score between $0-4$. The test was held to 34 students. The result of validity test showed that the Pearson Correlation coefficients of every item are greater than the critical value $\left(r_{x y}=0.3388\right)$ and 
reliability test showed that Cronbach Alpha test is $r_{11}=0.778$. It means that 8 items in mathematical understanding ability test instrument were valid and very reliable to measure calculus understanding ability of pre-service mathematics teachers.

\subsection{Learning Materials}

Learning materials used in this study were calculus textbook, worksheet for activity in the computer laboratory, worksheet for class discussion and exercises. Especially for the worksheets, the materials were developed by researchers follow genetic decomposition of the limit of function suggested by Dubinsky (Arnon et al., 2014) and derivative by Asiala, et al. (Font, et al., 2012). This is some instruction of the limit of function in the worksheet for activity in computer laboratory:

1) Students type some syntax of Maple which will guide them to construct the notion of the limit of a function definition

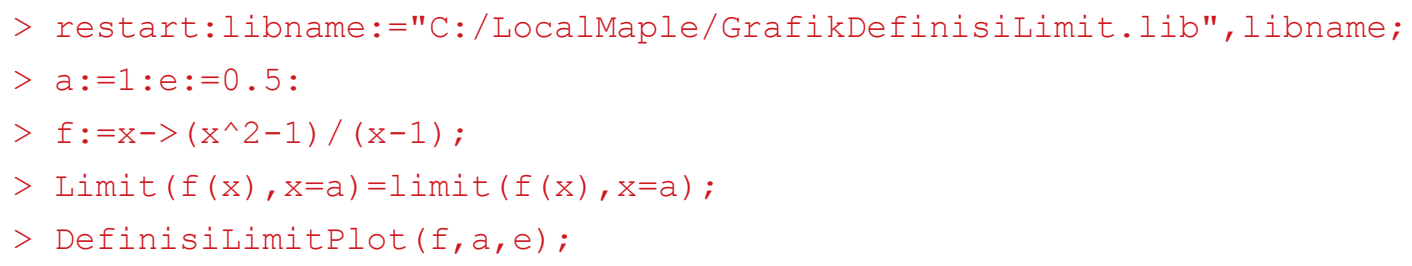

That syntax will call "DefinisiLimitPlot" procedure that was hidden in the computer system. The syntax will show a geometric representation of $\lim _{x \rightarrow 1}\left(\frac{x^{2}-1}{x-1}\right)=2$, that is, as follows:

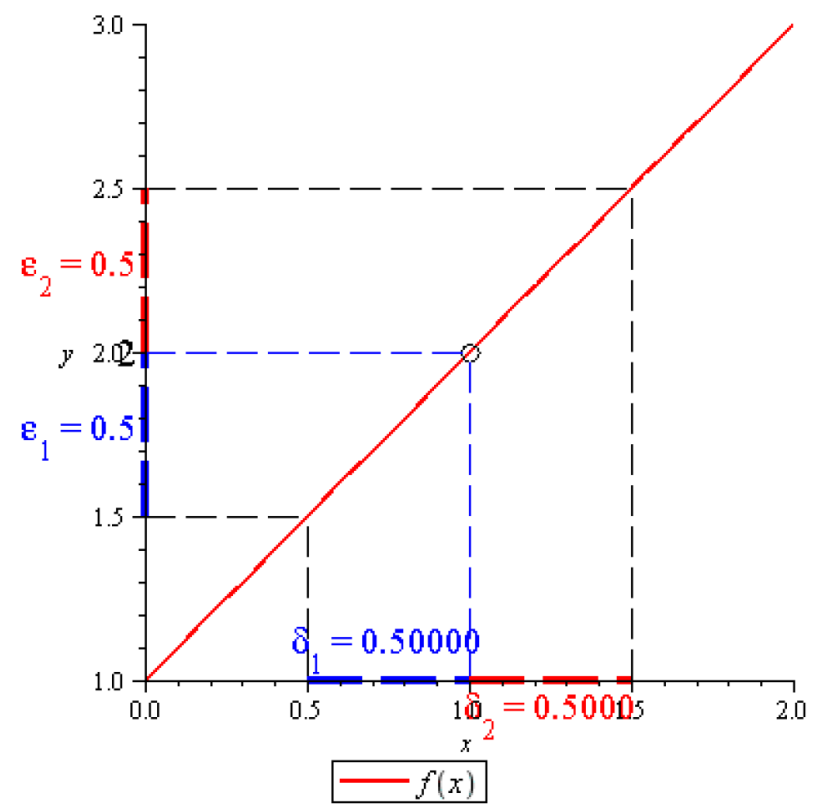

Figure 1. Geometric Representation of the Limit of A Function

2) Students can change the value of $\varepsilon$ and observe the graph changing.

3) After that, students are assigned to investigate, is the $\varepsilon$ and $\delta$ of $f(x)$ that is showed on computer screen accomplish a statement "if $0<|x-a|<\delta$, then $|f(x)-L|<\varepsilon$ "?

4) The lecturer will help students to apply the syntax and guide them to answer the questions in a worksheet. 
To understand derivative definition, the students were given instruction to typewriter some syntax that is as follows:

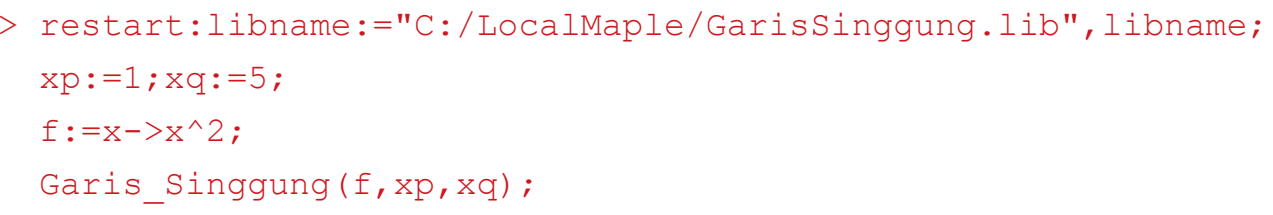

The syntax would show a secant animation that offends a curve by calling Garis_Singgung procedure. The students could change the value of $x_{p}, x_{q}$ and the function. After that, they were instructed to observe the animation. From that observation, they were assigned to solve, how is the equation of the tangent line on $y=f(x)$ at point $\left(x_{p}, f\left(x_{p}\right)\right)$ ? The output of the syntax is showed on Figure 2.

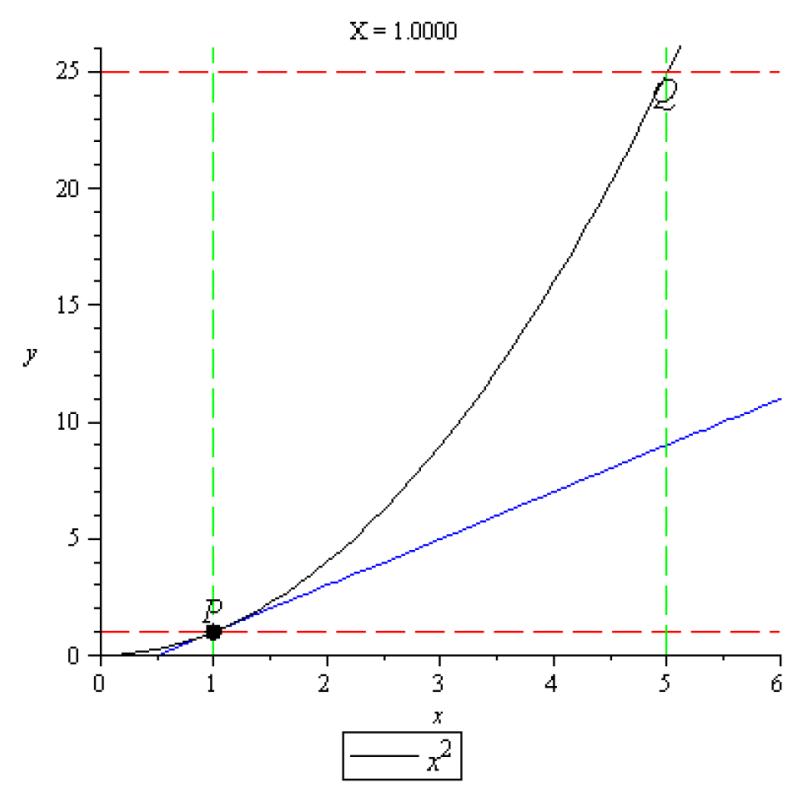

Figure 2. Geometry Representation of the Tangent Line on a Curve

After activity in the computer laboratory, the materials were discussed in class. This is some instruction in the worksheet for class discussion.

1) Students were assigned to solve some problems related to materials in the computer laboratory. They worked it in a group. The problems relate to the limit of a function were as follows:

If $x$ close to $c$ from left, then $f(x)$ close to $M$, but if $x$ close to $c$ from right, then $f(x)$ close to $L$. Illustrate it in a figure that appropriates the condition!

Is the $\lim _{x \rightarrow c} f(x)$ exist? Explain it!

For a problem relates to derivative, the example material that was given in experiment group is as follows:

Given the functions:
a) $f(x)=|x-6|$
b) $f(x)=\sqrt[3]{x}$
c) $f(x)=\left\{\begin{array}{c}x^{2}, x \leq 2 \\ 4-x, x>2\end{array}\right.$ 
Are the functions differentiable at every point in its domain? Explain it!

2) The lecturer will guide the discussion.

For reinforcement, the students were given exercises. This is one of the problems relate to the limit of a function that must be worked by them outside of class.

For $\lim _{x \rightarrow 2}\left(x^{2}-3 x+4\right)=2$, Find $\delta$ appropriate with $\varepsilon=0.2$ and $\varepsilon=0.1$

For a problem relates to derivative, the example material that was given in experiment group is as follows:

The number of bacteria after $\mathrm{t}$ hour in a laboratory experiment is $n=f(t)$.

a) What is the meaning of $f^{\prime}(5)$ ?

b) If the supply of nutrients for bacteria is limited, what conclusions can be drawn on conditions $f^{\prime}(10)$ ?

\subsection{Data Analysis Technique}

Data in this study was quantitative data. The data was obtained through pre and post of mathematical understanding ability test. The data analysis technique has three stages. First, the data of mathematical understanding ability test was analyzed descriptively with a procedure as follows:

1. Give the value of mathematical understanding ability for every research subject with the formula:

$$
\text { Value }=\frac{\text { sum of score obtained by subject }}{\text { maximum score }} \times 100
$$

2. Convert the value and categorize it into very good, good, moderate, low, or very low

Second, the data obtained from pre and posttest was analyzed to know the improvement of students' mathematical understanding ability at experiment and control class with a procedure as follows:

1. Calculate the data improvement with n-gain formula from Hake (1999), that is:

$$
\mathrm{n} \text {-gain }=\frac{\text { posttest value }- \text { pretest value }}{\text { maximum possible value }- \text { pretest value }}
$$

2. Interpret the result of n-gain and classify it into high, average, or low.

Third, the data of $\mathrm{n}$-gain was analyzed with a procedure as follows:

1. Normality test of the data

2. Homogeneity test of the data

3. Determine statistic test assisted SPSS software. If the data is not normal or the variance is not homogeneous, then the data will be tested with a non-parametric statistic, otherwise, the parametric statistic will be used, that is, t-test and two ways ANOVA.

\section{Results and Discussion}

\subsection{The Results of Data Analysis}

Data obtained in this study was quantitative data from the result of mathematical initial ability test and mathematical understanding test. Mathematical initial ability in this study was an ability which describes students initial knowledge about calculus preliminary before ACE teaching cyclic is applied in experiment class and direct learning is applied in control class. It was known by a test. Beside to know the description of students' mathematics initial ability, it was also used to categorize them in a group of high, average, or 
low ability. Descriptive statistic of pre-service mathematics teachers' mathematical initial ability at experiment and control class is presented in the Table 1.

Table 1 shows that the means of students' mathematical initial ability from both classes are categorized low ability in $0-100$ scales. It indicated most of the pre-service mathematics teachers will find difficulty in comprehending the limit of function and derivative. Henceforth, to know the difference of mathematical initial ability from both classes, t-test or Mann-Whitney $U$ was used. Precondition test result of mathematical initial ability showed that there are non-normal data; even so, the variance is homogenous. It means the difference test used Mann-Whitney $U$ test. The result showed that Asymp Sig. $=0.525>0.05$ so that the null hypothesis is accepted. It means that there was no significant difference between the means value of students' mathematical initial ability in experiment and control class. It also showed that there are no superior classes that will influence significantly to the dependent variable. Besides that, the value was used to organize the students in a group of ability. A group category, according to Arikunto (2012), is based on means and standard deviation. The $1^{\text {st }}$ category is if the score of students' mathematical initial ability greater than or equal to 45.431 , then the student is categorized high ability. The $2^{\text {nd }}$ category is if the score of students' mathematical initial ability is between 13.787 and 45.431 , then the student is categorized average ability. The last category is if the score of students' mathematical initial ability less than 13.787, then the student is categorized low ability. From those categories, the data distribution of students' mathematical initial ability and its descriptive statistic can be seen in the Table 2 .

Table 2 gives a description that the means value of pre-service mathematics teachers mathematical initial ability at experiment and control class was actually categorized as average, low, and very low ability in $0-100$ scales. Many researchers have studied the relationship between students' initial ability with their academic achievements, such as Hevriansyah and Megawanti (2016), Firmansyah (2017), and Lestari (2017). They stated that initial ability gives significant influence to the learning outcome. It means that pre-service mathematics teachers' mathematical initial ability related to their mathematical understanding ability. Statistic descriptive about the enhancement of pre-service mathematics teachers' mathematical understanding ability is presented in Table 3.

Table 3 shows that n-gain score of students' mathematical understanding ability who get ACE teaching cyclic was less than students who get direct learning in terms of students overall, group of low and average mathematical initial ability, except students' group of high mathematical initial ability. It means that ACE teaching cyclic based on APOS theory only could enhance the mathematical understanding ability of group pre-service mathematics teachers categorized high mathematical initial ability, whereas other students' groups are seen could be enhanced by direct learning. Nevertheless, the enhancement was still classified very low in $0-1$ scale. This means both learning factors could not contribute significantly yet to enhance pre-service mathematics teachers' mathematical understanding ability on the limit of function and derivative. The analysis did not describe yet the results of this study comprehensively. Advance analysis of the n-gain was continued through inferential statistic test.

Enhancement data of pre-service mathematics teachers' mathematical understanding ability was a value obtained from n-gain formula according to Hake (1999). Advance analysis of the data used t-test and two ways ANOVA. T-test was used to test the difference between pre-service mathematics teachers' mathematical understanding ability who get ACE teaching cyclic and direct learning in terms of overall and groups of mathematical initial ability, whereas two ways ANOVA to test the interaction between learning factors (APOS and direct learning) and groups of mathematical initial ability (high, average, and low) to the enhancement of mathematical understanding ability of pre-service mathematics teachers.

In advance analysis, normality and homogeneous of the data variance test were done first. Normality test result of $\mathrm{N}$-gain data of overall students' mathematical understanding ability showed that $\mathrm{K}-\mathrm{S}$ value in experiment class is 0.091 with a sig. $=0.200$, whereas control class is 0.064 with sig. $=0.200$. It means that the data from both classes distributed normally, because of their sig. values were greater than 
$\alpha=0.05$. For homogenous of data variance test, the result showed that its Levene statistic is 1.237 with a sig. $=0268$. It means the variance data from both classes were homogenous, because of its sig. value was also greater than $\alpha=0.05$. The result of normality and the homogeneous of data variance test shows that t-test could be used as a tool to analyze the difference between pre-service mathematics teachers' mathematical understanding ability who get ACE teaching cyclic and direct learning in terms of overall. The result of $\mathrm{N}$-gain data difference test of overall students' mathematical understanding ability in experiment and control class is presented in the Table 4.

Table 4 shows sig. value is greater than 0.05 that means null hypothesis is accepted. It leads to a conclusion that there was no significant difference between the enhancement of pre-service mathematics teachers' mathematical understanding ability who get ACE teaching cyclic and direct learning in terms of students overall. This revised a result of the descriptive analysis which the enhancement of pre-service mathematics teachers' mathematical understanding ability who get direct learning was not better yet than students who get ACE teaching cyclic.

\begin{tabular}{|c|c|c|c|c|c|}
\hline \multirow[b]{2}{*}{ Class } & \multirow[b]{2}{*}{$n$} & \multicolumn{2}{|c|}{ Value } & \multirow[b]{2}{*}{ Mean } & \multirow{2}{*}{$\begin{array}{l}\text { Standard } \\
\text { Deviation }\end{array}$} \\
\hline & & Min & $\operatorname{Max}$ & & \\
\hline Experiment & 62 & 3.226 & 71.774 & 30.000 & 14.769 \\
\hline Control & 58 & 4.194 & 71.613 & 29.191 & 16.996 \\
\hline Overall & 120 & 3.226 & 71.774 & 29.609 & 15.822 \\
\hline
\end{tabular}

Table 1. Descriptive Statistic of Pre-Service Mathematics Teachers' Mathematical Initial Ability

\begin{tabular}{|c|c|c|c|c|c|c|}
\hline \multirow{2}{*}{$\begin{array}{l}\text { Ability } \\
\text { Group }\end{array}$} & \multirow[b]{2}{*}{ Class } & \multirow[b]{2}{*}{$n$} & \multicolumn{2}{|c|}{ Value } & \multirow[b]{2}{*}{ Mean } & \multirow{2}{*}{$\begin{array}{l}\text { Standard } \\
\text { Deviation }\end{array}$} \\
\hline & & & Min & $\operatorname{Max}$ & & \\
\hline \multirow{2}{*}{ High } & Experiment & 11 & 45.806 & 71.774 & 54.604 & 7.887 \\
\hline & Control & 11 & 46.129 & 71.613 & 57.522 & 8.363 \\
\hline \multirow{2}{*}{ Average } & Experiment & 45 & 13.871 & 44.839 & 26.771 & 8.093 \\
\hline & Control & 36 & 14.839 & 42.742 & 26.241 & 8.760 \\
\hline \multirow{2}{*}{ Low } & Experiment & 6 & 3.226 & 12.581 & 9.113 & 3.343 \\
\hline & Control & 11 & 4.194 & 13.710 & 10.513 & 3.149 \\
\hline
\end{tabular}

Table 2. Descriptive Statistic of Students' Mathematical Initial Ability Group

\begin{tabular}{|l|l|r|r|r|r|r|}
\hline \multicolumn{1}{|c|}{$\begin{array}{c}\text { Ability } \\
\text { Group }\end{array}$} & \multicolumn{1}{|c|}{ Learning Factor } & $\boldsymbol{n}$ & \multicolumn{1}{c|}{ Min } & \multicolumn{1}{c|}{ Max } & \multicolumn{1}{c|}{ Mean } & $\begin{array}{c}\text { Standard } \\
\text { Deviation }\end{array}$ \\
\hline \multirow{2}{*}{ High } & ACE Teaching Cyclic & 11 & -0.042 & 0.316 & 0.089 & 0.107 \\
\cline { 2 - 7 } & Direct Learning & 11 & -0.143 & 0.205 & 0.032 & 0.107 \\
\hline \multirow{2}{*}{ Average } & ACE Teaching Cyclic & 45 & -0.120 & 0.266 & 0.057 & 0.080 \\
\cline { 2 - 7 } & Direct Learning & 36 & -0.123 & 0.284 & 0.092 & 0.097 \\
\hline \multirow{2}{*}{ Low } & ACE Teaching Cyclic & 6 & -0.078 & 0.203 & 0.052 & 0.107 \\
\cline { 2 - 7 } & Direct Learning & 11 & -0.011 & 0.207 & 0.092 & 0.073 \\
\hline \multirow{2}{*}{ Overall } & ACE Teaching Cyclic & 62 & -0.120 & 0.316 & 0.062 & 0.087 \\
\cline { 2 - 7 } & Direct Learning & 58 & -0.143 & 0.284 & 0.081 & 0.096 \\
\hline
\end{tabular}

Table 3. N-Gain Descriptive Statistic of Students' Mathematical Understanding Ability

\begin{tabular}{|l|r|r|r|r|}
\hline \multicolumn{1}{|c|}{ Learning Factor } & \multicolumn{1}{c|}{$\boldsymbol{n}$} & \multicolumn{1}{c|}{ Sig. (2-tailed) } & \multicolumn{1}{c|}{$\boldsymbol{H}_{\mathbf{0}}$} \\
\hline ACE Teaching Cyclic & 62 & -1.082 & 0.282 & Accepted \\
\hline Direct Learning & 58 & & & \\
\hline
\end{tabular}

Table 4. The Difference Test Result of N-Gain Data of Overall Students'

Mathematical Understanding Ability Based on Learning Factor 
After analysis in terms of students overall, next analysis is to investigate the difference between the enhancement of pre-service mathematics teachers' mathematical understanding ability who get ACE teaching cyclic and direct learning in terms of students' mathematical initial ability groups. Before that, normality and homogeneous of the data variance test were done to the data. The result of normality test of n-gain data of students' mathematical understanding ability in terms of mathematical initial ability group showed that the data distributed normally, because their sig. value $>0,05$ so that $\mathrm{H}_{0}$ was accepted. For homogenous of data variance test, the result showed that Levene statistic of high ability group is 0.000 with a sig. $=0.996$, whereas Levene statistic of average ability group is 2.069 with a sig. $=0.154$. For the last group, its Levene statistic is 2.126 with a sig. $=0.165$. It means the variance data from three groups were homogenous, because of their sig. value was greater than $\alpha=0.05$. Because use the data was normal and its variance was homogenous, the difference test for each group used t-test. The result of the t-test is presented in Table 5

Based on Table 5, the result shows that null hypothesis was accepted. It means that there was no significant difference between the enhancement of pre-service mathematics teachers' mathematical understanding ability who get ACE teaching cyclic and direct learning in terms of each initial ability group. This result corresponds with the n-gain analysis result in terms of students overall. This result also clarifies that the result of descriptive analysis about the enhancement of pre-service mathematics teachers' mathematical understanding ability who get direct learning was better than students who get ACE teaching cyclic in terms of low and average mathematical initial ability group, except high group is not exactly right yet.

The last analysis is to investigate the interaction between learning factor (ACE teaching cyclic and direct learning) and the group of mathematical initial ability (high, average, and low) to the enhancement of the mathematical understanding ability of pre-service mathematics teachers. Based on normality and homogenous of data variance test result of the enhancement of mathematical understanding ability described earlier, interaction test could be used two ways ANOVA. The result is presented in the Table 6 .

Table 6 shows that null hypothesis of the interaction between both factors was accepted. It means that there was no significant interaction between learning factor (ACE teaching cyclic and direct learning) and the group of mathematical initial ability (high, average, and low) to the enhancement of the mathematical understanding ability of pre-service mathematics teachers. In another word, there was no significant difference between the enhancement of pre-service mathematics teachers' mathematical understanding ability who get ACE teaching cyclic and direct learning is not influenced or depended on mathematical initial ability group or there was no significant difference between the enhancement of pre-service mathematics teachers' mathematical understanding ability of low, average, and high mathematical initial ability group is not influenced or depended on ACE teaching cyclic and direct learning.

\begin{tabular}{|c|c|c|c|c|c|}
\hline $\begin{array}{l}\text { Ability } \\
\text { Group }\end{array}$ & Learning Factor & $\mathrm{n}$ & $\mathrm{t}$ & $\begin{array}{c}\text { Sig. } \\
\text { (2-tailed) }\end{array}$ & $H_{0}$ \\
\hline \multirow{2}{*}{ High } & ACE Teaching Cyclic & 11 & \multirow{2}{*}{1.233} & \multirow{2}{*}{0.232} & \multirow{2}{*}{ Accepted } \\
\hline & Direct Learning & 11 & & & \\
\hline \multirow{2}{*}{ Average } & ACE Teaching Cyclic & 45 & \multirow{2}{*}{-1.755} & \multirow{2}{*}{0.083} & \multirow{2}{*}{ Accepted } \\
\hline & Direct Learning & 36 & & & \\
\hline \multirow{2}{*}{ Low } & ACE Teaching Cyclic & 6 & \multirow{2}{*}{-0.902} & \multirow{2}{*}{0.381} & \multirow{2}{*}{ Acceptec } \\
\hline & Direct Learning & 11 & & & \\
\hline
\end{tabular}

Table 5. The Difference Test Result of N-Gain Data of Students' Mathematical Understanding Ability Based on Learning Factor and Initial Ability Group 


\begin{tabular}{|l|r|r|r|r|r|r|}
\hline \multicolumn{1}{|c|}{ Source } & \multicolumn{1}{c|}{$\begin{array}{c}\text { Sum of } \\
\text { Square }\end{array}$} & \multicolumn{1}{c|}{$\boldsymbol{d f}$} & \multicolumn{1}{c|}{ Mean of Square } & \multicolumn{1}{c|}{$\boldsymbol{F}$} & \multicolumn{1}{c|}{ Sig. } & $\boldsymbol{H}_{\mathbf{0}}$ \\
\hline Initial Ability Group & 0.003 & 2 & 0.002 & 0.201 & 0.818 & Accepted \\
\hline Learning Factor & 0.001 & 1 & 0.001 & 0.075 & 0.785 & Accepted \\
\hline Interaction & 0.038 & 2 & 0.019 & 2.256 & 0.109 & Accepted \\
\hline
\end{tabular}

Table 6. Two Ways ANOVA Result of the Enhancement of Students' Mathematical Understanding Ability

\subsection{Discussion}

In this study, learning factors was investigated concern to ACE teaching cyclic in experiment class and direct learning applied in control class. The investigation was to know the influence of both learning factors in enhancing the mathematical understanding ability of pre-service mathematics teachers. In terms of students overall, the descriptive analysis result showed that enhancement of pre-service mathematics teachers' mathematical understanding ability who get direct learning is better than students' who get ACE teaching cyclic in terms of students overall, low and average mathematical initial ability group, whereas high group showed vice versa. Advance analysis result uses inferential statistic test showed there is no significant difference between the enhancements of both classes. It means that ACE teaching cyclic based on APOS theory gave an influent to enhance the mathematical understanding ability of pre-service mathematics teachers but not significant yet. This finding supported Slavickova (2009) and Herlina (2015) studies, whereas Arnawa (2007), Hartati (2014), and Anwar, Mandailina and Pramita (2018) studies showed a different result. According to Slavickova (2009), that occurs because students learn to solve a mathematics problem without understanding and they are unusual self-learning. Herlina (2015) also revealed that undergraduate students who become her research subject difficult to change their habits of learning from teacher-centered to student-centered, only students with high ability play an active role in a group and class discussion, and her students still could not solve mathematics problems completely yet. The experience occurs in this study was not different with two studies before. Observation result in this study showed that when students in the computer laboratory, most of them do activities begun with typewriting Maple syntax. After that, they observed output result in the computer screen. The output related to the problems in students worksheet. When they answered the problems, most of the students with high ability were seen try to solve them, while students with average ability observed and sometimes discuss actively during seek the solution, whereas students with the low ability only wait and note when the answer was found. That atmosphere occurred too when students discuss in class which it was dominated by students with high ability.

In ACE teaching cyclic, the phase after students' activities in computer laboratory and class is a phase which students were assigned to completely mathematics task outside class. From their answers, there were still found some errors. It means pre-service mathematics teachers did not accomplish yet the tasks optimally. This also indicates that students with high ability did not optimize their ability. The indication was proven true when one of them is interviewed. The interview result revealed that the student only tries to solve the easy problems or similar with example explained by the lecturer, unmotivated when meeting the complex problems and does not explore Maple as an assistant tool to accomplish mathematics tasks. That phenomenon caused mathematical understanding ability of pre-service mathematics teachers does not reach the enhancement significantly.

The result of this study also revealed that direct learning can enhance the mathematical understanding ability of pre-service mathematics teachers in control class which the contribution is not different with ACE teaching cyclic. This is because they have gotten used to every treatment in direct learning. In the treatments, students paid attention to lecturer explanations about the material and problems examples, noted it, got a chance to ask material that has not been understood, paid attention to their friends' questions, got a chance to respond the explanation or answer of their friends, solve the problems chosen in textbooks, demonstrated their works in front of class, and got a chance to respond their friends' work. That all treatments were seen can make students actively in few parts on the learning process, but did not give them a chance to construct mathematics knowledge by themselves widely (Afgani et al., 2017). Different with ACE teaching cyclic based on APOS theory, the treatments in this learning factors give a 
chance to students construct mathematics knowledge by themselves at first through learning material that is arranged and designed based on genetic decomposition. Genetic decomposition of the limit of function suggested by Dubinsky (Arnon et al., 2014) and derivative by Asiala et al. (1996) (Font, Trigueros, Badillo \& Rubio, 2012) was used as a guide to developing learning material in this study. Nevertheless, a changing on unusual treatment make students need to adapt quickly because about one semester is only a time period given to them in this study. In a view of enhancement of mathematical understanding ability, pre-service mathematics teachers in experiment class could not adapt quickly to the learning atmosphere designed according to ACE teaching cyclic based on APOS theory. According to Kober (2015), students need time to adapt to a new pedagogic approach. Meanwhile, the obstacles found by researcher can be used as a reflection to develop the approach gets better.

The results of enhancement of pre-service mathematics teachers' mathematical understanding ability in experiment and control class have been predictable from the result of their mathematical initial ability. The result has given a description of the obstacles will be experienced by them in understanding the limit of function and derivative. From analysis result of their answer to mathematical understanding ability test in experiment and control class, the students experienced very difficult in applying the limit of function or derivative concept to solve the mathematics problem. This finding was supported by Mendezabal and Tindowen (2018)'s study. They reported that the students do not much understand the material of basic calculus so their understanding in differential calculus is categorized fair. One of the examples from students answer relate to that indicator is presented in the following figure.

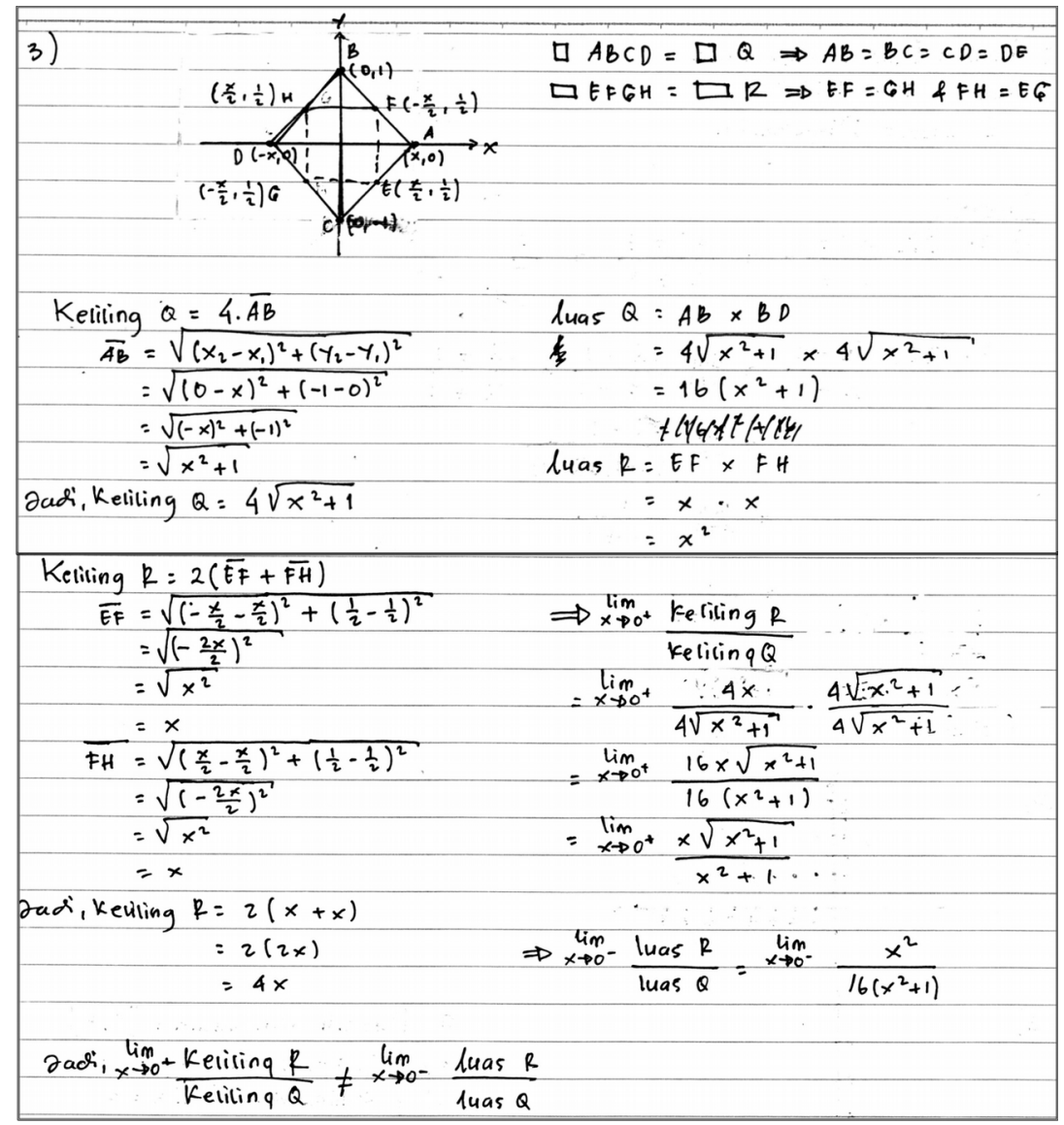

Figure 3. Example of Student Answer

The student did not identify the problem comprehensively. The student viewed that $\mathrm{Q}$ is a rectangle and $\mathrm{R}$ is a square. The view on $\mathrm{R}$ is an error of that student. $\mathrm{R}$ can be a square, but it also can be a quadrangle which all sides have equal length, but the angles are not right-angled absolutely. Because that error, the student could not achieve the indicator. Besides that, they also difficult to explain differentiability of a 
function that involves absolute value in square root, prove the statement validity about a derivative of the function, apply the derivative concept of function in problem-solving, and solve a problem related to a derivative of the function. They did not too much experience difficulty to determine the value of limit on simple rational function. It indicated there are five indicators hard to achieve. Difficulties occurred to pre-service mathematics teachers in answering mathematical understanding ability test have been indicated by the result of their mathematical initial ability that classifies in low ability.

From discussion result above, ACE teaching cyclic based on APOS theory potentially could enhance the mathematical understanding ability of pre-service mathematics teachers, but this pedagogic approach needs time in its application. This is because implementation during one semester did not optimize students' mathematical understanding ability yet. Another reason is their mathematical initial ability was classified as low ability. This is also one of the casual factors make the students in this study did not adapt quickly in ACE teaching cyclic. Therefore, the pedagogic approach needs continuity implementation to pre-service mathematics teachers on next semester and not only implemented in calculus class to see the influence.

\section{Conclusion}

Based on the result of this study, we concluded that 1) there is no significant difference of the enhancement of mathematical understanding ability between pre-service mathematics teachers applied ACE teaching cyclic based on APOS theory with pre-service mathematics teachers applied direct learning in terms of overall or mathematical initial ability group, 2) there is no significant interaction between learning factor (ACE teaching cyclic and direct learning) and group of mathematical initial ability (high, average, and low) to the enhancement of mathematical understanding ability of pre-service mathematics teachers. Based on the conclusion, we recommended 1) to investigate other indicators about mathematical understanding ability relate to APOS theory, 2) to give students a chance to construct mathematics knowledge by his/herself with a longer time, and more encouraging students with low ability to play an active role in group and class discussion, and 3) to develop learning material more effectively based on genetic decomposition suggested by the previous study, because learning material in this study was not optimal yet to enhance students' mathematical understanding ability.

\section{Acknowledgments}

The Author extends gratitude to Raden Fatah State Islamic University which have given GOI scholarship, so that author could participate as a student in Indonesia University of Education. Last but not least, author render thanks and gives respect very greatful to all other individuals who have supported author to writing this paper.

\section{Declaration of Conflicting Interests}

The authors declared no potential conflicts of interest with respect to the research, authorship, and/or publication of this article.

\section{Funding}

The authors received financial support from GOI scholarship for the research, authorship, and/or publication of this article.

\section{References}

Afgani, M.W., Suryadi, D., \& Dahlan, J.A. (2017). Analysis of Undergraduate Students' Mathematical Understanding Ability of the Limit of Function Based on APOS Theory Perspective. Journal of Physics: Conference Series, 895(012056). https://doi.org/10.1088/1742-6596/895/1/012056

Anwar, Y.S., Mandailina, V., \& Pramita, D. (2018). Efektivitas Penerapan Teori APOS Terhadap Hasil Belajar Persamaan Diferensial pada Mahasiswa Program Studi Pendidikan Matematika Tahun Akademik 2012/2013. Paedagoria: Jurnal Kajian Penelitian dan Pengembangan Kependidikan, FKIP UM Mataram, 51-54. 
Arikunto, S., (2012). Dasar-Dasar Evaluasi Pendidikan. Jakarta: Bumi Aksara.

Arnawa, I.M. (2007). Mengembangkan Kualitas Pemahaman dalam Aljabar Abstrak melalui Pembelajaran Berdasarkan Teori APOS. Jurnal Pendidikan dan Kebudayaan, 13(068), 809-826.

https://doi.org/10.24832/jpnk.v13i68.402

Arnon, I., Cottrill, J., Dubinsky, E., Oktac, A., Fuenstes, S.R., Trigueros, M. et al. (2014). APOS Theory: A Framework for Research and Curriculum Development in Mathematics Education. New York: Springer Science+Business Media. https://doi.org/10.1007/978-1-4614-7966-6

Asiala, M., Brown, A., DeVries, D.J., Dubinsky, E., Mathews, D., \& Thomas, K. (1996). A framework for research and curriculum development in undergraduate mathematics education, Research in Collegiate Mathematics Education II, CBMS Issues in Mathematics Education, 6, 1-32. https://doi.org/10.1090/cbmath/006/01

Bautista, R.C. (2013). The Students' Procedural Fluency and Written-Mathematical Explanation on Constructed Response Tasks in Physics. Journal of Technology and Science Education, 3(1), 49-56. https://doi.org/10.3926/jotse.68

De Castro, C.H. (2011). Assessing the Impact of Computer Programming in Understanding Limits and Derivatives in a Secondary Mathematics Classroom. Dissertation, ScholarWorks. Georgia State University.

Ernest, P. (2004). The Philosophy of Mathematics Education. British: Taylor \& Francis e-Library.

Firmansyah, M.A. (2017). Peran Kemampuan Awal Matematika dan Belief Maatematika Terhadap Hasil Belajar. Prima: Jurnal Pendidikan Matematika, 1(1), 55-68. https://doi.org/10.31000/prima.v1i1.255

Font, V., Trigueros, M., Badillo, E., \& Rubio, N. (2012). What is A Mathematical Object? Looking to Objects from Two Theoretical Perspectives: APOS and OSA. In $12^{\text {th }}$ International Congress on Mathematical Education. COEX, Seoul, Korea.

Hake, R. (1999). Analyzing Change/Gain Scores. Available at: http://www.physics.indiana.edu/-sdi/AnalyzingChangeGain.pdf.html

Hartati, S.J. (2014). Design of Learning Model of Logic and Algorithms Based on APOS Theory. International Journal of Evaluation and Research in Education (IJERE), 3(2), 109-118. https://doi.org/10.11591/ijere.v3i2.5743

Herlina, E. (2015). Meningkatkan Advanced Mathematical Thinking Mahasiswa. Infinity: Jurnal Ilmiah Program Studi Matematika STKIP Siliwangi Bandung, 4(1), 65-83. https://doi.org/10.22460/infinity.v4i1.73

Hevriansyah, P., \& Megawanti, P. (2016). Pengaruh Kemampuan Awal Terhadap Hasil Belajar Matematika. Jurnal Kajian Pendidikan Matematika, 02(01), 37-44.

Jojo, Z. (2013). Mathematics Begins with Direct Human Experience: An APOS Approach to Conceptual Understanding of A Mathematical Concept. Proceedings ISTE International Conference on Mathematics, Science and Technology Education. University of South Africa, Unisa Press.

Kober, N. (2015). Reaching Students: What Research Says About Effective Instruction in Undergraduate Science and Engineering. Washington, USA: The National Academics Press.

Lestari, W. (2017). Pengaruh Kemampuan Awal Matematika dan Motivasi Belajar Terhadap Hasil Belajar Matematika. Jurnal Analisia, 3(1), 76-84. https://doi.org/10.15575/ja.v3i1.1499

Maharaj, A. (2010). An APOS Analysis of Students' Understanding of the Concept of A Limit of A Function. Pythagoras, 71, 41-52. https://doi.org/10.4102/pythagoras.v0i71.6 
Mendezabal, M.J.N., \& Tindowen, D.J.C. (2018). Improving Students' Attitude, Conceptual Understanding and Procedural Skills in Differential Calculus through Microsoft Mathematics. Journal of Technology and Science Education. 8(4), 385-397. https://doi.org/10.3926/jotse.356

Mrdja, M., Romano, D.A., \& Zubac, M. (2015). Analysis Of Students' Mental Structures When Incorrectly Calculating The Limit Of Functions. IMVI Open Mathematical Education Notes., 5(2), 101-113.

Ningsih, Y.L. (2016). Kemampuan Pemahaman Konsep Matematika Mahasiswa Melalui Penerapan Lembar Aktivitas Mahasiswa (LAM) Berbasis Teori APOS pada Materi Turunan. Edumatica, 06(01), 1-8.

Rosita, C.D., Laelasari, L., \& Noto, M.S. (2014). Analisis Kemampuan Pemahaman Matematis Mahasiswa pada Mata Kuliah Aljabar Linear 1. Jurnal Euclid, 1(2), 60-69.

Salleh, T.S.A., \& Zakaria, E. (2013). Enhancing Students' Understanding in Integral Calculus through the Integration of Maple in Learning. Procedia - Social and Behavioral Sciences, 102, 204-211. https://doi.org/10.1016/j.sbspro.2013.10.734

Skemp, R.R. (1976). Relational Understanding dan Instrumental Understanding. Published in Mathematics Teaching, 77, 22-26.

Simatwa, E.M.W. (2010). Piaget's Theory of Intellectual Development and Its Implication for Instructional Management at Pre-Secondary School Level. Educational Research and Reviews, 5(7), 366-371.

Siyepu, S.W. (2015). Analysis of Errors in Derivatives of Trigonometric Functions. International Journal of STEM Education, 2(16). https://doi.org/10.1186/s40594-015-0029-5

Slavickova, M. (2009). Using Graphic Calculus on Calculus Lessons. Acta Didactica Universitatis Comenianae Mathematics, 9, 109-122.

Stacey, K. (2006). What Is Mathematical Thinking and Why Is It Important? ResearchGate, 39-48.

Syahbana, A. (2013). Peningkatan Kemampuan Pemahaman Matematis Mahasiswa Melalui Penerapan Strategi Metakognitif. Edumatica, 03(02), 1-12.

Syaiful (2014). Student Comprehension About Line and Row From APOS Theory Point of View. Proceeding International Seminar on Innovation in Mathematics and Mathematics Education $1^{\text {st }}$ ISIM-MED (563-570). Department of Mathematics Education, Yogyakarta State University.

Zahid, M.Z., Sujadi, I., \& Sari, D.R. (2014). Eksplorasi Konstruksi Pengetahuan Matematika Siswa Kelas VIII SMP Negeri 1 Surakarta Menggunakan Teori APOS pada Materi Pokok Faktorisasi Bentuk Aljabar. Jurnal Elektronik Pembelajaran Matematika, 2(7), 714-726.

Published by OmniaScience (www.omniascience.com) Journal of Technology and Science Education, 2018 (www.jotse.org)

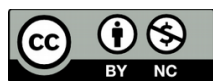

Article's contents are provided on an Attribution-Non Commercial 4.0 Creative commons International License. Readers are allowed to copy, distribute and communicate article's contents, provided the author's and JOTSE journal's names are included. It must not be used for commercial purposes. To see the complete licence contents, please visit https://creativecommons.org/licenses/by-nc/4.0/. 